\title{
Importance of culture history on $17 a$-ethinylestradiol cometabolism by nitrifying sludge
}

\author{
Angkana Jantanaprasartporn ${ }^{1,2}$, Suppasil Maneerat ${ }^{3}$, Chaiwat Rongsayamanont ${ }^{2,4^{+}}$ \\ ${ }^{1}$ International Postgraduate Programs in Environmental Management, Graduate School, Chulalongkorn University, Bangkok 10330, Thailand \\ ${ }^{2}$ Center of Excellence on Hazardous Substance Management (HSM), Bangkok 10330, Thailand \\ ${ }^{3}$ Biotechnology for Bioresource Utilization Laboratory, Department of Industrial Biotechnology, Faculty of Agro-Industry, Prince of Songkla University, \\ Songkhla 90110, Thailand \\ ${ }^{4}$ Environmental Assessment and Technology for Hazardous Waste Management Research Center, Faculty of Environmental Management, Prince of \\ Songkla University, Songkhla 90110, Thailand
}

\begin{abstract}
17 $\alpha$-ethinylestradiol (EE2), a synthetic estrogen which interfere the endocrine and reproductive function in living organisms, has been found extensively to be deposited into municipal wastewater treatment plants and the environment via human excretion. EE2 has long been known to be efficiently cometabolized by ammonia-oxidizing bacteria $(\mathrm{AOB})$ during ammonia $\left(\mathrm{NH}_{3}\right)$ oxidation. Current study aims to investigate the effect of culture history on the biotransformation of EE2 by nitrifying sludge which was enriched under different ammonia loading rates in continuous flow reactors. Result showed that past growth condition largely affected not only the metabolic rate of $\mathrm{NH}_{3}$ oxidation but also EE2 cometabolism. Sludge previously acclimated with higher $\mathrm{NH}_{3}$ loads as well as sludge dominated with AOB belong to high growth cluster (Nitrosomonas europaea-Nitrosococcus mobilis) showed higher rate of EE2 biotransformation than those one being acclimated with lower $\mathrm{NH}_{3}$ loads because of its ability to provide more reducing power from $\mathrm{NH}_{3}$ oxidation. Moreover, the correlation between the degradation rates of $\mathrm{NH}_{3}$ and EE2 was higher in sludge being acclimated with higher load of $\mathrm{NH}_{3}$ in comparison with other sludge. Implication of the findings emphasized the role of volumetric $\mathrm{NH}_{3}$ loading rate in determining EE2 removal in wastewater treatment system.
\end{abstract}

Keywords: Ammonia-oxidizing bacteria, Cometabolism, Culture history, Nitrifying sludge, 17a-ethinylestradiol

\section{Introduction}

Estrogens are essential group of hormones that regulate the growth and development of female sexual characteristics in humans and animals. Estrogens strongly interfere with endocrine and reproductive functions in living organisms including disturbance on immunological system and fertility, reproductive failure due to thinning of eggshells and reduction in egg production [1], feminization and masculinization, and altered sexual development [2]. $17 \alpha$-ethinylestradiol (EE2), a synthetic estrogen, is generally used as the oral contraceptive pill to control the birth rate and hormone therapy. EE2 prompt to be released to the environment via human excretion which is later discharged into municipal wastewater treatment plants (WWTS) as hotspots for the release of estrogens in the environment [3].
Some estrogens are able to be degraded in the WWTS. The estrogens removal efficiencies in activated sludge process range from $61 \%$ to $98 \%$ for estrone (E1), $67 \%$ and $99 \%$ for estradiol (E2) and $85 \%$ to $90 \%$ for EE2 [4]. Natural estrogens (E1 and E2) are readily metabolized by heterotrophic microorganisms in WWTS, while the biodegradation of more recalcitrant hormone like EE2 is known mainly through cometabolism of ammonia monooxygenase enzyme (AMO) by ammonia-oxidizing bacteria (AOB) $[5,6]$. Some essential factors like the availability of ammonia $\left(\mathrm{NH}_{3}\right)$ as the growth substrate of $\mathrm{AOB}$ [5] have been investigated for its roles on EE2 cometabolism by AMO. However, microorganism generally produce enzyme and other macromolecules at a rate which is unique to their previous growth condition [7, 8], therefore, the culture history of AOB may be another factor determining not only the rate of $\mathrm{NH}_{3}$ utilization [9] but also the rate of EE2 cometabolism.
This is an Open Access article distributed under the terms of the Creative Commons Attribution Non-Commercial License (http://creativecommons.org/licenses/by-nc/3.0/) which permits unrestricted non-commercial use, distribution, and reproduction in any medium, provided the original work is properly cited.
Received April 8, 2017 Accepted July 18, 2017

${ }^{\dagger}$ Corresponding author

Email: milesgodfather@yahoo.com

Tel: +66-7428-6839 Fax: +66-7442-9758

Copyright (C) 2018 Korean Society of Environmental Engineers 
For all of the reasons above, this study aims to determine effect of culture history on EE2 cometabolism by autotrophic AOB. AOB was enriched in mixed culture at different growth conditions. Effect of growth substrate concentration on bacterial cometabolism was also investigated. Although the past growth condition could potentially affect the bacterial cometabolism, but influence of the culture history of AOB on its EE2 cometabolism has never been investigated.

\section{Materials and Methods}

\subsection{Chemicals}

EE2 (17 $\alpha$-ethinylestradiol) was purchased from Sigma-Aldrich Corporation (St. Louis, MO, USA). The stock solution of EE2 was prepared to $500 \mathrm{mg} / \mathrm{L}$ in methanol. Other chemicals were purchased from Carlo Erba Reagents (Val de Reuil, France). All chemicals used in this study are analytical reagent grade.

\subsection{Enrichment Media for $A O B$}

Enrichment media, which consist of synthetic wastewater plus $\mathrm{NH}_{3}$ at various concentrations, was used for enrichment of AOB. Synthetic wastewater A was prepared by dissolving $\mathrm{NaCl}$ (1 g), $\mathrm{MgCl}_{2} \bullet 6 \mathrm{H}_{2} \mathrm{O}(0.4 \mathrm{~g}), \mathrm{CaCl}_{2} \cdot 2 \mathrm{H}_{2} \mathrm{O}(0.1 \mathrm{~g}), \mathrm{KH}_{2} \mathrm{PO}_{4}(0.2 \mathrm{~g})$, and $\mathrm{KCl}$ $(0.5 \mathrm{~g})$ into one liter of de-ionized (DI) water and then adding one milliliter $(\mathrm{mL})$ of each mineral solutions including the solution of non-chelated trace element, selenite-tungstate, vitamin mixture, thiamine, vitamin B12 [10]. Synthetic wastewater A was added with $0.34 \mathrm{~g}$ of $\left(\mathrm{NH}_{4}\right)_{2} \mathrm{SO}_{4}$ per liter to achieve final $\mathrm{NH}_{3}$ concentration of $70 \mathrm{mg} \mathrm{N} / \mathrm{L}$. Synthetic wastewater B, which contained $\mathrm{Na}_{2} \mathrm{HPO}_{4}$ (4.05 g), $\mathrm{K}_{2} \mathrm{HPO}_{4}(2.1 \mathrm{~g}), \mathrm{MgSO}_{4} \cdot 7 \mathrm{H}_{2} \mathrm{O}(0.05 \mathrm{~g}), \mathrm{CaCl}_{2} \cdot 2 \mathrm{H}_{2} \mathrm{O}$ (0.01 g), and $\mathrm{FeSO}_{4} \cdot 7 \mathrm{H}_{2} \mathrm{O}$ (0.09 g) in one liter of DI water [11], was added with 0.68 and $2.02 \mathrm{~g}$ of $\left(\mathrm{NH}_{4}\right)_{2} \mathrm{SO}_{4}$ per liter to make up final $\mathrm{NH}_{3}$ concentrations of 140 and $420 \mathrm{mg} \mathrm{N} / \mathrm{L}$, respectively. Synthetic wastewater A and B were further used to prepare medium for batch degradation test.

\subsection{Enriched Reactors Setup and Operation}

Three vessels with an effective volume of 6 liters were identically set up as continuous flow enriched reactors without cell recycle. For each reactor, air was supplied from air blower connecting with a small stone diffuser to provide oxygen and mix the mixed liquor completely. The concentration of dissolved oxygen (DO) in bulk solution was maintained between $7-8 \mathrm{mgO}_{2} / \mathrm{L}$ by adjusting air flow rate with a small needle valve. $\mathrm{pH}$ in mixed liquor was controlled at $7.5 \pm 0.2$ by a pH controller (Liquitron DP 5000, LMI Milton Roy, USA) equipped with a $\mathrm{pH}$ probe (Orion 9156DJWP, Thermo scientific, UK) as well as a solution of $0.5 \mathrm{~N} \mathrm{HCl}$ and $0.5 \mathrm{~N} \mathrm{NaOH}$. Reactors were operated at room temperature between $23-25^{\circ} \mathrm{C}$. Mixed liquor taken from full scale activated sludge process was used as inoculum to start up the reactors. Enriched reactors were operated differently in order to enrich AOB which belongs to different growth characteristics. Enrichment medium containing $\mathrm{NH}_{3}$ was continuously fed into each one of three reactors at different $\mathrm{NH}_{3}$ concentrations to enrich the AOB population which belongs to different rates of $\mathrm{NH}_{3}$ utilization. The reactors named '70NS', '140NS' and '420NS' were fed with $\mathrm{NH}_{3}$ of 70, 140 and $420 \mathrm{mg}$ $\mathrm{N} / \mathrm{L}$ and controlled at sludge age of 4,3 , and $4 \mathrm{~d}$, respectively. For each gram of added $\mathrm{NH}_{3}, 0.068$ grams of $\mathrm{HCO}_{3}{ }^{-}$was put into an enrichment medium to provide carbon source for AOB growth.

\subsection{Batch Degradation Test}

\subsubsection{Reactor setup and operation}

Several $25 \mathrm{~mL}$ small Plexiglas ${ }^{\circledR}$ vessels, which were initially filled with synthetic wastewater, were used as batch reactors. Sludge taken from enriched reactors during steady operation were washed and inoculated into the batch reactors. Synthetic wastewater was later filled into batch reactors until final sludge concentration of $300 \mathrm{mg}$ mixed liquor suspended solid (MLSS)/L was reached. Then, a predetermined volume of the stock EE2 solution was added and fully mixed in order to achieve final EE2 concentration of $3 \mathrm{mg} / \mathrm{L}$ in the reactors. $\mathrm{NH}_{3}$ was later added into the reactors in a similar manner with that of EE2. Synthetic wastewater A was used particularly for tests with having initial $\mathrm{NH}_{3}$ levels of 28 and $70 \mathrm{mg} \mathrm{N} / \mathrm{L}$ while for tests belongs to the initial $\mathrm{NH}_{3}$ concentration of 140 and $420 \mathrm{mg} \mathrm{N} / \mathrm{L}$, wastewater B was used instead. Air and mixing was provided to mixed liquor by shaking in an orbital shaker at $250 \mathrm{rpm}$. The reactor was incubated at room temperature. While running the tests, $\mathrm{pH}$ in bulk solution was maintained within a range of $8.0 \pm 0.2$ by adding HEPES buffer solution to a final concentration of $30 \mathrm{~g} / \mathrm{L}$.

\subsubsection{Test procedure}

Sludge containing the AOB population which belongs to different the $\mathrm{NH}_{3}$ utilization rates was taken from each one of three enriched reactors during steady operation and then, brought into batch degradation tests. Various initial concentrations of $\mathrm{NH}_{3}$ were used in the tests in order to determine effect of growth substrate concentration on the rates of $\mathrm{NH}_{3}$ oxidation and EE2 degradation. Loss due to abiotic sorption and volatilization of $\mathrm{NH}_{3}$ and $\mathrm{EE} 2$ were observed through batch tests with heat-killed cell and without cell. EE2 biodegradability by heterotrophic microorganism in enriched sludge was investigated in the presence of $10 \mathrm{mg} / \mathrm{L}$ allylthiourea (ATU) for the suppression of the AMO usage by AOB [12]. Furthermore, $1,000 \mathrm{mg} / \mathrm{L}$ chloramphenicol was also added into the reactors in order to evaluate the $\mathrm{NH}_{3}$ and EE2 biodegradability remained in the harvested sludge under the suppression of AMO-induced de novo synthesis [13]. All tests were carried out in triplicate except the test with heat-treated cells and with no cells were done in duplicate. For all tests, samples were periodically collected and analyzed for the concentration of EE2 and inorganic nitrogen species in bulk solution for the whole two weeks of the test period.

\subsection{Chemical Analysis}

Mixed liquor samples were collected from enriched and batch reactors and then, filtered through $0.45 \mu \mathrm{m}$ Polytetrafluoroethylene membrane filter. Filtrate were analyzed for EE2 and inorganic nitrogen species $\left(\mathrm{NH}_{3}, \mathrm{NO}_{2}^{-}, \mathrm{NO}_{3}^{-}\right)$while filtrated were measured for MLSS and mixed liquor volatile suspended solid by gravimetric method. EE2 was analyzed by a C18 reversed-phase high-performance liquid chromatography with ultraviolet detector (Shimadzu 
Series LC-10ADvp) using a 60:40 acetonitrile: $\mathrm{H}_{2} \mathrm{O}$ as mobile phase. $\mathrm{NH}_{3}$ was measured by gas-sensitive combination electrode (Cole Palmer, Co.) and salicylated-colorimetric method with UV visible spectrophotometer (Thermo Electron Corporation, Hexious $\alpha$, Cambridge, UK) at $640 \mathrm{~nm}$ [14]. $\mathrm{NO}_{2}^{-}$was colorimetrically analyzed with UV visible spectrophotometer at $543 \mathrm{~nm}$ while $\mathrm{NO}_{3}^{-}$was analyzed by UV screening method at 220 and $275 \mathrm{~nm}$ [14]. $\mathrm{pH}$ DO concentration and temperature in mixed liquor were monitored during sludge enrichment and degradation test. $\mathrm{pH}$ value was determined by $\mathrm{pH}$ probe (250A+, Thermo Orion Inc., Germany). The concentration of DO was determined by membrane sensing electrode (DO 083005D probe with 850A meter, Thermo Orion Inc., Germany). Temperature was measured by a laboratory glass thermometer.

\subsection{Analysis of Ammonia-oxidizing Bacterial Communities}

\subsubsection{Sample preparation and DNA extraction}

Sludge samples (2 mg dry sludge/L) from two enriched reactors including '70NS' and '420NS' were concentrated via centrifugation at $14,000 \mathrm{rpm}$ for $10 \mathrm{~min}$ and stored at $-20^{\circ} \mathrm{C}$. Genomic DNA was extracted from each samples (2 mg dry sludge) using Fast-DNA SPIN kits for soil (QBiogenes, USA) following to the manufacturer's instruction. The extracted DNA was verified using 1.5\% agarose gel electrophoresis (Bio-Rad, Spain).

2.6.2. Polymerase chain reaction (PCR), cloning and sequencing Primers amoA $1 \mathrm{~F}$ and 2R [15] (forward 5-GGGGTTTCTACT GGTGGT-3; reverse 5-CCCCTCKGSAAAGCCTTCTTC-3) were used for PCR amplification. Bacterial amoA gene fragments were amplified using a Takara polymerase (Takara Bio Inc., Japan) in a thermal cycler (Biorad Laboratories, USA) for $10 \mathrm{~min}$ at $95^{\circ} \mathrm{C}$, followed by 35 cycles of $60 \mathrm{~s}$ at $95^{\circ} \mathrm{C}, 60 \mathrm{~s}$ at $56^{\circ} \mathrm{C}$, and $30 \mathrm{~s}$ at $72^{\circ} \mathrm{C}$, followed by $15 \mathrm{~min}$ of final extension at $78^{\circ} \mathrm{C}$. Later, the amplified PCR products were purified by gel electrophoresis using a NucleoSpin Extract II Kit (Clontech Laboratories Inc., USA). Then, the purified PCR products were cloned using the pGEM-T Easy vector system (Promega, USA). Later, five and four clones of '70NS' and '420NS' samples were randomly chosen for sequencing at Macrogen Inc., Korea, respectively.

\section{Results and Discussion}

\subsection{Enriched Reactors Performance}

Table 1 and Fig. 1 showed long-term performance of all three enriched reactors. All reactors showed steady performance in terms of $\mathrm{NH}_{3}, \mathrm{NO}_{2}^{-}$and $\mathrm{NO}_{3}^{-}$effluent concentrations after five weeks of operation. At steady state condition, $\mathrm{NH}_{3}$ removal efficiencies
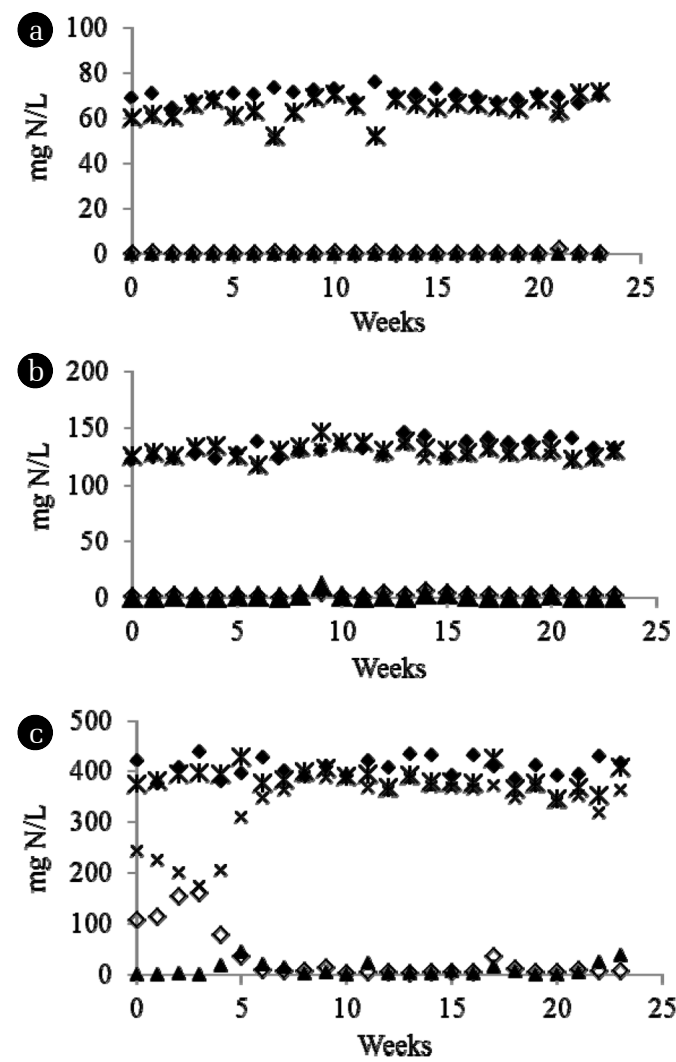

Fig. 1. Concentration profiles of inorganic nitrogen species during sludge enrichment with $\mathrm{NH}_{3}$ concentration of a) $70 \mathrm{mg} \mathrm{N} / \mathrm{L}$, b) $140 \mathrm{mg}$ $\mathrm{N} / \mathrm{L}$ and c) $420 \mathrm{mg} \mathrm{N} / \mathrm{L}$.

Table 1. System Performance of Enriched Reactors

\begin{tabular}{|c|c|c|c|}
\hline \multirow{3}{*}{ Parameter } & \multicolumn{3}{|c|}{ Treatment performance } \\
\hline & A & B & $\mathbf{C}$ \\
\hline & $70 \mathrm{mg} \mathrm{N} / \mathrm{L} \mathrm{NH}$-fed reactor & $140 \mathrm{mg} \mathrm{N} / \mathrm{L} \mathrm{NH} \mathrm{NH}_{3}$ fed reactor & $420 \mathrm{mg} \mathrm{N} / \mathrm{L} \mathrm{NH}_{3}$-fed reactor \\
\hline Influent $\mathrm{NH}_{3}(\mathrm{mg} \mathrm{N} / \mathrm{L})$ & $69.14 \pm 1.44$ & $138.05 \pm 3.79$ & $409.37 \pm 17.55$ \\
\hline $\mathrm{NH}_{3}$ loading rate $(\mathrm{mg} \mathrm{N} /(\mathrm{L}-\mathrm{d}))$ & $16.59 \pm 0.35$ & $33.13 \pm 0.91$ & $98.25 \pm 4.21$ \\
\hline Effluent $\mathrm{NH}_{3}(\mathrm{mg} \mathrm{N} / \mathrm{L})$ & $0.49 \pm 0.15$ & $1.95 \pm 0.58$ & $11.00 \pm 10.76$ \\
\hline $\mathrm{NH}_{3}$ oxidation rate (mg N/(gVSS-day)) & 219.7 & 275.0 & 637.4 \\
\hline Effluent $\mathrm{NO}_{2}^{-}$(mg N/L) & $0.12 \pm 0.08$ & $0.84 \pm 0.69$ & $12.35 \pm 13.16$ \\
\hline Effluent $\mathrm{NO}_{3}^{-}(\mathrm{mg} \mathrm{N} / \mathrm{L})$ & $66.47 \pm 3.38$ & $125.88 \pm 3.20$ & $353.55 \pm 18.40$ \\
\hline Total N & $67.09 \pm 3.01$ & $128.67 \pm 3.51$ & $376.90 \pm 27.03$ \\
\hline Dominated AOB cluster & $\begin{array}{c}\text { Nitrosomonas oligotropha } \\
\text { cluster }\end{array}$ & - & $\begin{array}{c}\text { Nitrosomonas europaea- } \\
\text { Nitrosococcus mobilis cluster }\end{array}$ \\
\hline
\end{tabular}


for reactors fed with $\mathrm{NH}_{3}$ of $70 \mathrm{mg} \mathrm{N} / \mathrm{L}$ and $140 \mathrm{mg} \mathrm{N} / \mathrm{L}$ were more than 99\%. But for $420 \mathrm{mg} \mathrm{N} / \mathrm{L} \mathrm{NH}_{3}$-fed reactor, a slight less efficiency for $\mathrm{NH}_{3}$ removal (96.23\%) was observed due to receiving higher $\mathrm{NH}_{3}$ load compared to other reactors. In addition, an increase in $\mathrm{NH}_{3}$ load led to stimulate specific $\mathrm{NH}_{3}$ oxidation rate. $\mathrm{No} \mathrm{NO}_{2}^{-}$accumulated in any reactors indicating $\mathrm{NH}_{3}$ oxidation is the rate determining step for nitrification.

\subsection{Ammonia-oxidizing Bacterial Communities in Enriched Sludge}

Sludge '70NS' and '420NS' were brought to further analyze for ammonia-oxidizing bacterial communities using PCR-cloning- sequencing technique. Results showed that AOB belongs to Nitrosomonas oligotropha ( $N$. oligotropha) cluster dominated (4 of 5 clones) in reactor fed with $\mathrm{NH}_{3}$ of $70 \mathrm{mg} \mathrm{N} / \mathrm{L}$ at which the $\mathrm{NH}_{3}$ concentration were less than $1 \mathrm{mg} \mathrm{N} / \mathrm{L}$ in effluent (Table 1). AOB belongs to $N$. oligotropha cluster is known as a high $\mathrm{NH}_{3}$ affinity cluster as indicated by low Monod half-saturated coefficient ( $\mathrm{K}_{\mathrm{s}}$ : 0.32-3.16 mg N/L [16, 17]). However, reactor fed with $420 \mathrm{mg} \mathrm{N} / \mathrm{L} \mathrm{NH}_{3}$, which its effluent contained $15.82 \mathrm{mg} \mathrm{N} / \mathrm{L} \mathrm{NH}_{3}$, was dominated (all 4 clones) by AOB belongs to Nitrosomonas europaea-Nitrosoccus mobilis (N. europaea-N. mobilis) cluster. AOB belongs to N. europaea-N. mobilis cluster has much lower $\mathrm{NH}_{3}$ affinity than that belongs to $N$. oligotropha cluster as indicated by much higher $\mathrm{K}_{\mathrm{s}}$ (1-100 mg N/L, [16-19]). These results corresponded with the finding reported in Limpiyakorn et al. [20]. Limpiyakorn et al. [20] showed that $N$. europaea-N. mobilis cluster dominated in chemostats fed with $>140 \mathrm{mg} \mathrm{N} / \mathrm{L} \mathrm{NH}_{3}$ while for the reactor fed with $\leq 140 \mathrm{mg} \mathrm{N} / \mathrm{L} \mathrm{NH}_{3}$, the dominant AOB belonged to $N$. oligotropha cluster.

\subsection{Batch $\mathrm{NH}_{3}$ Oxidation}

\subsubsection{Effect of culture history}

In order to investigate effect of continuous culture history on batch substrate utilization, three enriched sludge being acclimated with various loads of the growth substrate ('70NS', '140NS', and '420NS') were brought to determine the rate of substrate utilization under batch condition. Results showed that continuous culture history of enriched sludge strongly influence on batch $\mathrm{NH}_{3}$ oxidation rate (Table 2). For any given values of initial $\mathrm{NH}_{3}$ concentration, higher $\mathrm{NH}_{3}$ oxidation rate was found in sludge previously being acclimated with higher load of $\mathrm{NH}_{3}$.

This is likely because continuous cultivation of mixed sludge at higher $\mathrm{NH}_{3}$ load leading to the selection for a particular AOB having higher $\mathrm{NH}_{3}$ utilization rate. Generally, the dominant bacterial population mainly determined the rate of substrate utilization and bacterial growth of mixed culture. Sludge dominated by AOB with $N$. europaea-N. mobilis cluster (420NS) showed higher batch $\mathrm{NH}_{3}$ utilization rate as compared with that of dominated by $N$. oligotropha AOB cluster (70NS). For all results shown above, an intrinsic $\mathrm{NH}_{3}$ oxidation rate clearly depended on the physiology of dominant AOB population in enriched nitrifying sludge.

\subsubsection{Effect of initial $\mathrm{NH}_{3}$ concentration}

As a result, $\mathrm{NH}_{3}$ oxidation was limited by substrate availability. Larger specific $\mathrm{NH}_{3}$ oxidation rate was observed at higher initial $\mathrm{NH}_{3}$ (Fig. 2). However, maximum batch $\mathrm{NH}_{3}$ oxidation rate of enriched sludge was attained under initial $\mathrm{NH}_{3}$ concentration which had been previously used for feeding during sludge enrichment. Enriched sludge in reactors fed with $70 \mathrm{mg} \mathrm{N} / \mathrm{L}$ $\mathrm{NH}_{3}$ (70NS) achieved its maximum $\mathrm{NH}_{3}$ oxidation rate at 70 $\mathrm{mg} \mathrm{N} / \mathrm{L}$ while at least $140 \mathrm{mg} \mathrm{N} / \mathrm{L}$ was needed by sludge taken from the 140 and $420 \mathrm{mg} \mathrm{N} / \mathrm{L} \mathrm{NH}_{3}$-fed reactors (140NS and $420 \mathrm{NS}$ ). In other words, $N$. oligotropha-dominating sludge (70NS) achieved its maximum $\mathrm{NH}_{3}$ oxidation rate at lower $\mathrm{NH}_{3}$ concentration than that of sludge dominated with $N$. europaea-N. mobilis AOB cluster (420NS). Higher $\mathrm{NH}_{3}$ affinity of the 70NS as compared to that of the $420 \mathrm{NS}$ because it was dominated by the $N$. oligotropha cluster which has higher $\mathrm{NH}_{3}$ affinity than the N. europaea-N. mobilis cluster.

Moreover, at initial $\mathrm{NH}_{3}$ concentration of $420 \mathrm{mg} \mathrm{N} / \mathrm{L}$, slight lower $\mathrm{NH}_{3}$ was oxidized as a result of substrate inhibition. However, sludge dominated with $N$. oligotropha AOB cluster (70NS) were

Table 2. Comparison of the Rates of EE2 Degradation by Nitrifying Activated Sludge and Enriched Nitrifying Sludge in Aerated Batch Reactor

\begin{tabular}{|c|c|c|c|c|}
\hline Culture & $\begin{array}{l}\text { EE2 degradation rate } \\
\text { (mg/(gVSS-day)) }\end{array}$ & $\begin{array}{c}\mathrm{NH}_{3} \text { oxidation rate } \\
\text { (mg } \mathrm{N} /(\text { gVSS-day)) }\end{array}$ & $\begin{array}{l}\text { Initial concentration of } \\
\text { EE2 \& } \mathrm{NH}_{3}\end{array}$ & Ref \\
\hline Nitrifying activated sludge & 0.0936 & 1,320 & $\begin{array}{c}1.0 \mathrm{mg} / \mathrm{L} \mathrm{EE} 2 ; \\
100 \mathrm{mg} \mathrm{N} / \mathrm{L} \mathrm{NH}_{3}\end{array}$ & [12] \\
\hline AMO-containing extract from enriched nitrifying sludge & $7.83-29.17$ & 129.6-1,339.2 & - & {$[23]$} \\
\hline Enriched nitrifying sludge & 0.096 & 1,260 & $\begin{array}{c}0.75 \mathrm{mg} / \mathrm{L} \mathrm{EE} 2 ; 52.5 \mathrm{mg} \\
\mathrm{N} / \mathrm{L} \mathrm{NH}\end{array}$ & [26] \\
\hline Nitrifying activated sludge & 0.024 & 933.6 & $\begin{array}{l}0.05 \mathrm{mg} / \mathrm{L} \mathrm{EE} 2 ; \\
50 \mathrm{mg} \mathrm{N} / \mathrm{L} \mathrm{NH} \mathrm{NH}_{3}\end{array}$ & {$[28]$} \\
\hline \multicolumn{5}{|l|}{ Enriched nitrifying sludge } \\
\hline a70NS (N.oligotropha-dominating) & ${ }^{\mathrm{a}} 0.28-0.52$ & ${ }^{\mathrm{a}} 51.1-225.4$ & $3.0 \mathrm{mg} / \mathrm{L} \mathrm{EE} 2 ;$ & This \\
\hline b $140 \mathrm{NS}$ & b $0.31-0.66$ & b $67.5-312.7$ & $28-420 \mathrm{mg} \mathrm{N} / \mathrm{L}$ & study \\
\hline${ }^{\mathrm{c}} 420 \mathrm{NS}$ (N.europaea-dominating) & ${ }^{\mathrm{c}} 0.44-0.88$ & ${ }^{\mathrm{c}} 150.9-630.7$ & $\mathrm{NH}_{3}$ & \\
\hline
\end{tabular}



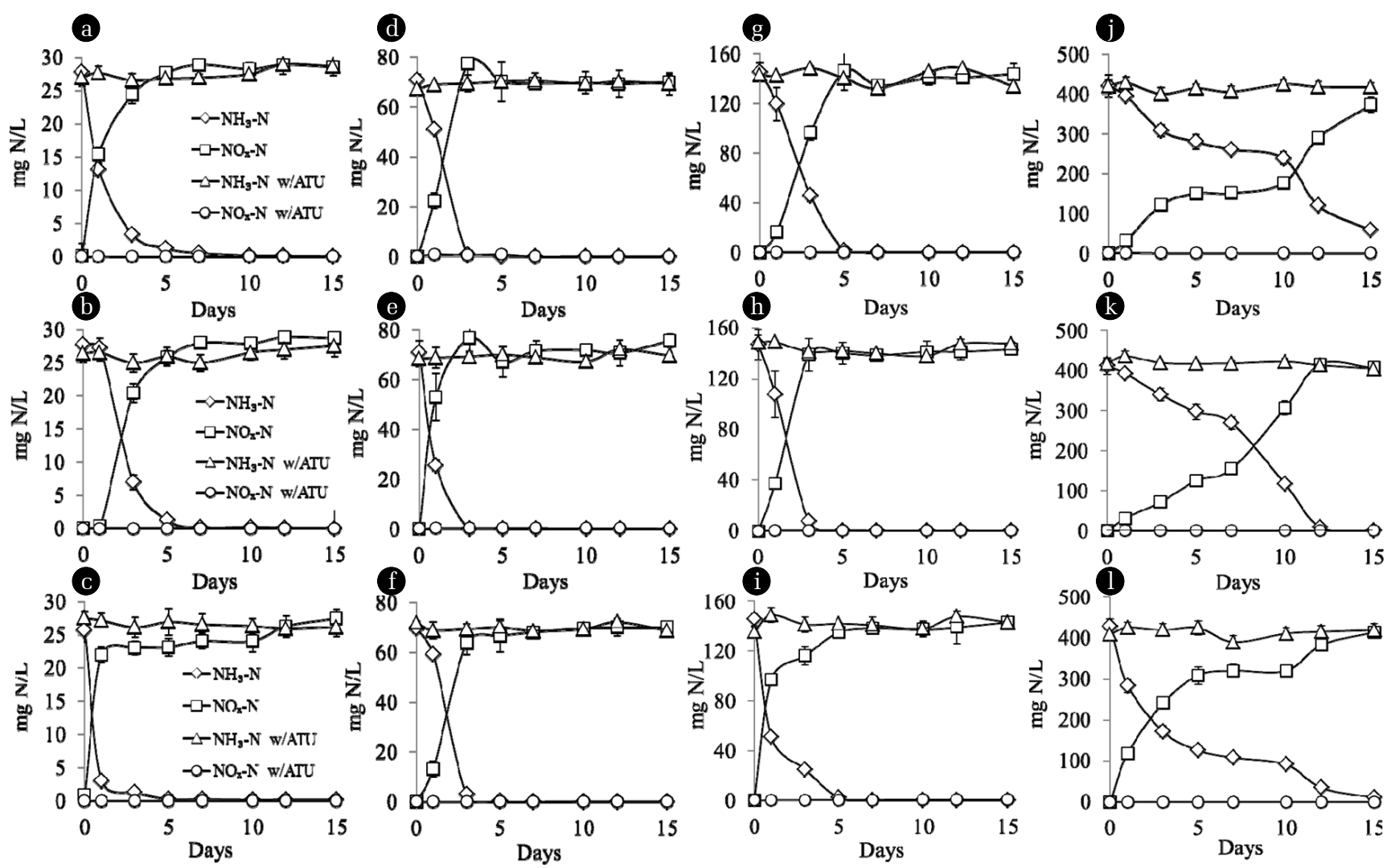

Fig. 2. Profiles of $\mathrm{NH}_{3}$ and $\mathrm{NO}_{3}{ }^{-}$concentration during incubation test with and without adding $\mathrm{ATU}$ at initial $\mathrm{NH}_{3}$ concentration of 28 mg $\mathrm{N} / \mathrm{L}$ (a-c), $70 \mathrm{mg} \mathrm{N} / \mathrm{L}(\mathrm{d}-\mathrm{f}), 140 \mathrm{mg} \mathrm{N} / \mathrm{L}$ (g-i) and $420 \mathrm{mg} \mathrm{N} / \mathrm{L}$ (j-l) using sludge 70NS (a,d,g,j), 140NS (b,e,h,k) and 420NS (c,f,i,l).

apparently affected far less by the substrate inhibition than $N$. europaea-N. mobilis-dominating sludge indicating higher tolerability to adverse condition in slow-growing AOB. This emphasized an importance of past cultivation condition of sludge on its rate of substrate utilization in batch reactor.

\subsection{Batch EE2 Degradation}

EE2 biodegradation by sludge enriched with different loads of $\mathrm{NH}_{3}$ was investigated to observe effect of culture history on the AMO cometabolism. As shown in Fig. 2 and 3, $\mathrm{NH}_{3}$ and EE2 degradation was observed only in the absence of ATU. Furthermore, there was not any EE2 degradation in batch with heat-treated cells or no cell (data not shown) indicating the loss of EE2 due to abiotic processes (ie. sorption and volatilization) was negligible in our study. This indicates that AMO cometabolism by AOB is main degradation pathway of EE2 rather than heterotrophic and abiotic degradation that is correspondence to several studies [12, 21-25]. Moreover, EE2 and $\mathrm{NH}_{3}$ degradation in the presence of AMO-induced inhibitor was not found (data not shown) indicating residual AMO utilization by harvested cells in order to complete both substrate degradation was negligible.

EE2 biotransformation clearly depended on $\mathrm{NH}_{3}$ oxidation. During EE2 cometabolism, EE2 was degraded by using a reducing power from $\mathrm{NH}_{3}$ oxidation. Therefore, more $\mathrm{NH}_{3}$ was oxidized, higher EE2 was degraded via the cometabolism of AMO. Moreover, not only initial $\mathrm{NH}_{3}$ concentration largely affected on $\mathrm{NH}_{3}$ oxidation rate but on EE2 biotransformation rate as well. Higher available $\mathrm{NH}_{3}$ improved both the rates of $\mathrm{NH}_{3}$ and EE2 removals indicating a reductant-limiting condition for AMO metabolism and cometabolism. While a reductant-inhibiting condition decreased $\mathrm{NH}_{3}$ oxidation and EE2 degradation at initial $\mathrm{NH}_{3}$ of $420 \mathrm{mg} \mathrm{N} / \mathrm{L}$. The results shown here is in good agreement with previous studies [22-24] which found strong positive correlation between initial concentration of $\mathrm{NH}_{3}$ and batch EE2 biotransformation rate by nitrifying sludge.

In addition, after $5 \mathrm{~d}$ of sludge incubation with initial $\mathrm{NH}_{3}$ of 28-140 mg N/L, all $\mathrm{NH}_{3}$ were utilized, but substantial biotransformation of EE2 was still occurring even in the absence of $\mathrm{NH}_{3}$. This was consistent with the results obtained by a number of studies [22, 26-28] which revealed the capability of nitrifying sludge to cometabolize EE2 in $\mathrm{NH}_{3}$-free environment. This phenomenon is likely to be a result of utilizing AMO accumulated within the $\mathrm{AOB}$ cell for degrading EE2 during $\mathrm{NH}_{3}$-limiting condition.

Moreover, EE2 degradation of enriched sludge was affected by not only initial $\mathrm{NH}_{3}$ level but also the enrichment condition. Higher EE2 biotransformation rate was achieved by sludge previously being enriched with higher $\mathrm{NH}_{3}$ load (Fig. 4). As mentioned earlier, the enrichment of nitrifying bacteria at higher $\mathrm{NH}_{3}$ load may pro 

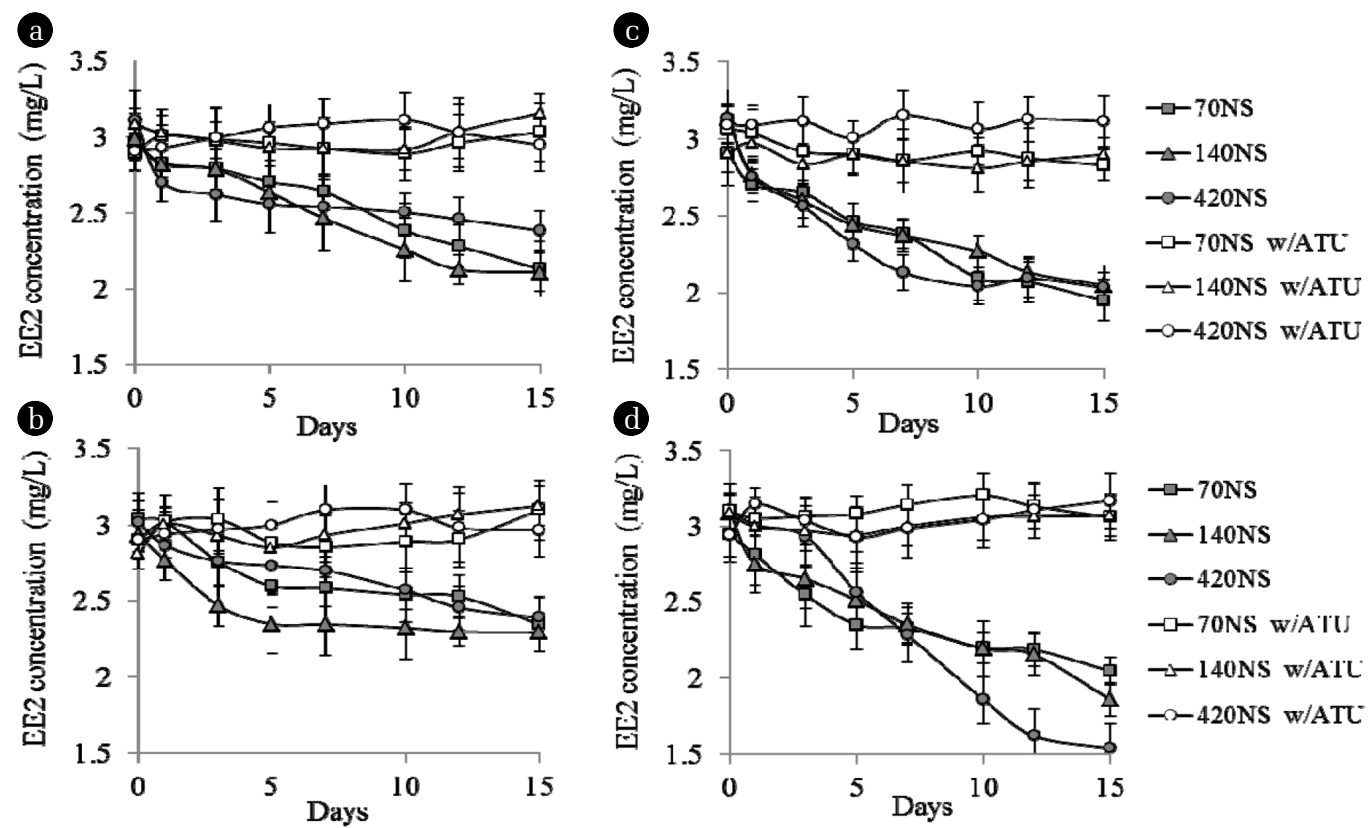

Fig. 3. EE2 degradation using different sludge at initial $\mathrm{NH}_{3}$ concentration a) $\left.\left.28 \mathrm{mg} \mathrm{N} / \mathrm{L} \mathrm{b}\right) 70 \mathrm{mg} \mathrm{N} / \mathrm{L} \mathrm{c)} 140 \mathrm{mg} \mathrm{N} / \mathrm{L} \mathrm{d}\right) 420 \mathrm{mg} \mathrm{N} / \mathrm{L}$.
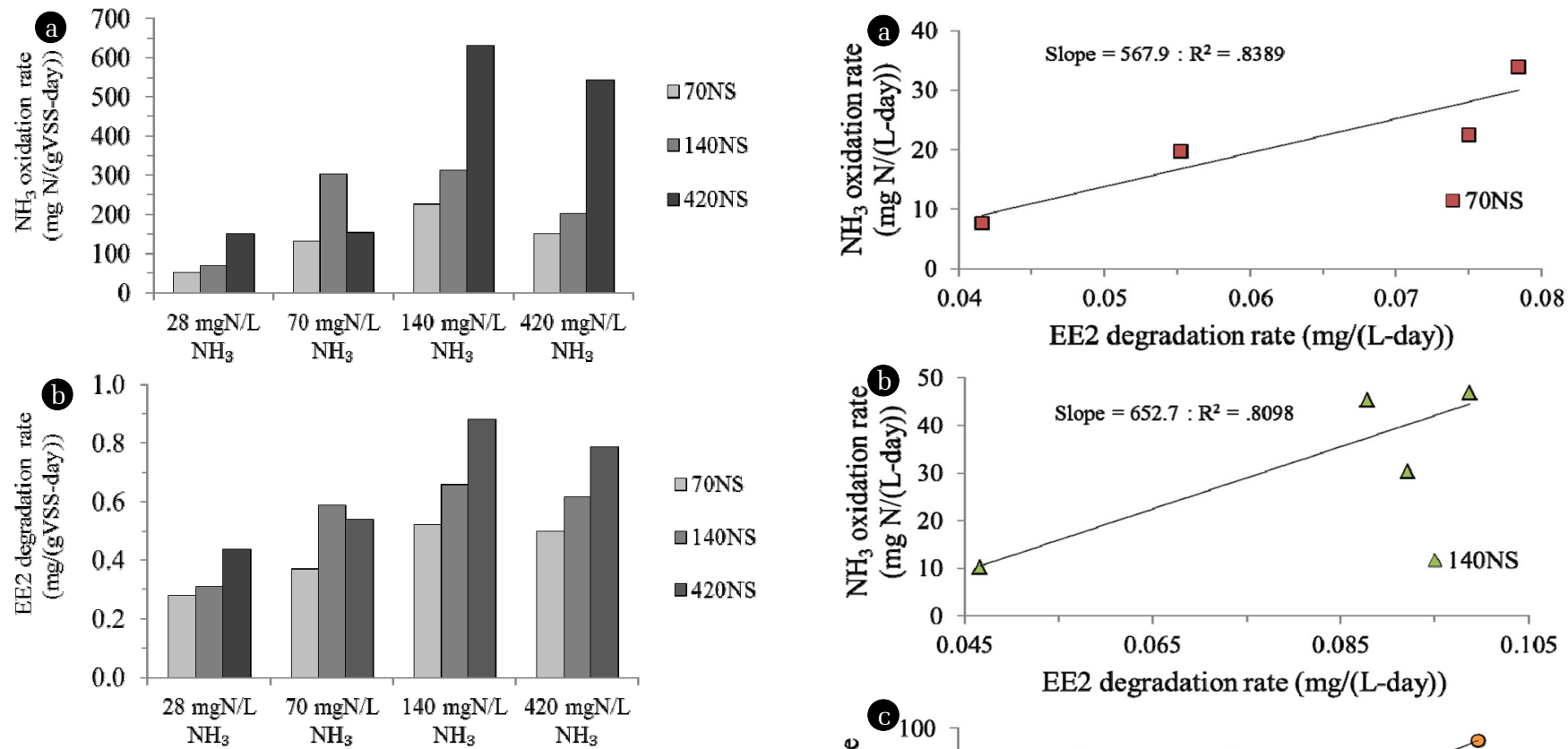

Fig. 4. The degradation rate of a) $\mathrm{NH}_{3}$ and b) EE2 under different sludge and initial $\mathrm{NH}_{3}$ concentrations.

mote specific $\mathrm{AOB}$ having higher utilization rate of $\mathrm{NH}_{3}$ over those having the lower one. The results show that AOB population in enriched nitrifying sludge affected on the EE2 degradation in the same manner as $\mathrm{NH}_{3}$ oxidation. Higher EE2 degradation was found in sludge dominated by higher-growth-AOB than lower-growth- AOB-dominating sludge. EE2 cometabolic rate of sludge dominated with the $N$. europaea- $N$. mobilis AOB cluster were approximately 1.6-1.7 (420NS) times higher than that belongs to
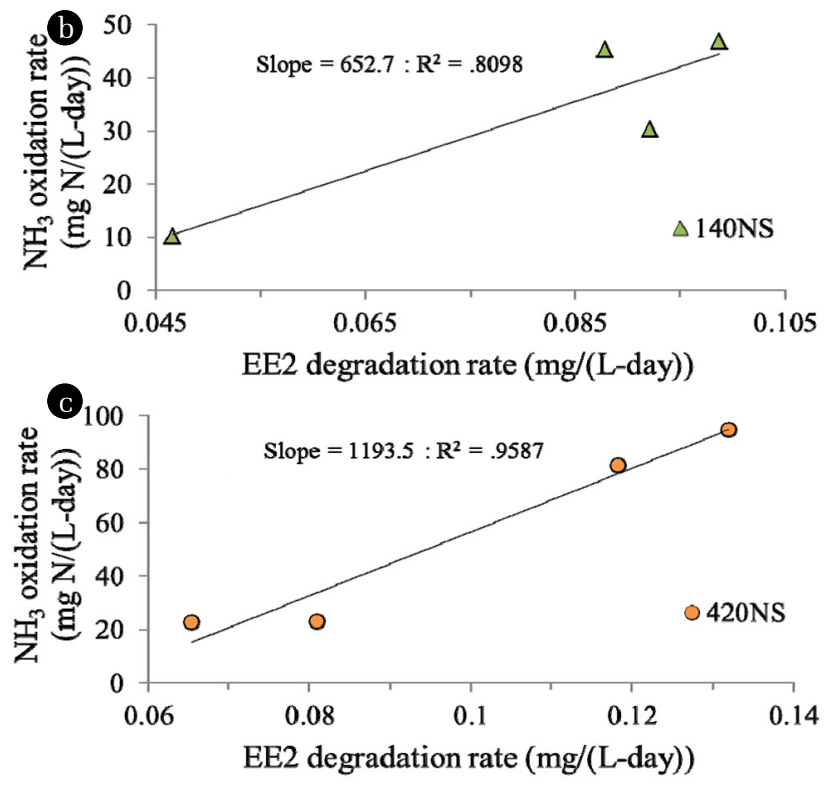

Fig. 5. The relationship between $\mathrm{NH}_{3}$ and EE2 degradation rates for a) $70 \mathrm{NS}$ b) $140 \mathrm{NS}$ c) $420 \mathrm{NS}$. 
the $N$. oligotropha AOB cluster (70NS). Greater EE2 cometabolic rate of higher-growth-AOB may be caused by more electron available for cometabolism.

Furthermore, the correlation between $\mathrm{NH}_{3}$ and EE2 degradation rates of sludge was found strongest in the sludge being previously cultivated with highest $\mathrm{NH}_{3}$ load (Fig. 5). It can be implied that more electron provided by $\mathrm{NH}_{3}$ oxidation is needed by sludge being previously cultivated with the highest load of $\mathrm{NH}_{3}$ to cometabolize a certain amount of EE2. Our finding firstly reveals the importance of past AOB growth condition regarding its determination on simultaneous $\mathrm{N}$ and EE2 removals. The rates of EE2 biotransformation found in this study were compared with those reported in previous studies (Table 2). Higher rates of EE2 degradation obtained in this study as compared to other studies is likely because much higher initial concentration of EE2 was used.

\section{Conclusions}

This research firstly determined the importance of culture history of nitrifying sludge on simultaneous $\mathrm{NH}_{3}$ and EE2 removals in wastewater. Higher available $\mathrm{NH}_{3}$ improved both the rates of $\mathrm{NH}_{3}$ and EE2 removals indicating a reductant-limiting condition for AMO metabolism and cometabolism. Sludge being acclimated with higher $\mathrm{NH}_{3}$ load as well as the one dominated with higher-growing-AOB showed higher rate of EE2 cometabolism due to its ability to provide more reducing power from $\mathrm{NH}_{3}$ oxidation. The $\mathrm{NH}_{3}$ and EE2 degradation rates were found having a stronger correlation particularly in sludge being previously cultivated with higher $\mathrm{NH}_{3}$ load.

\section{Acknowledgments}

The research was supported by a grant from Prince of Songkla University, contract no. ENV550371S.

\section{References}

1. Scholz S, Gutzeit HO. 17 $\alpha$-ethinylestradiol affects reproduction, sexual differentiation and aromatase gene expression of the medaka (Oryzias latipes). Aquat. Toxicol. 2000;50:363-373.

2. Hester RE, Harrison RM, Phillips B, Harrison P. Overview of the endocrine disrupters issue. In: Harrison RM and Hester RE, eds. Endocrine disrupting chemicals. London: Royal Society of Chemistry; 1999. p. 1-26.

3. Lust MJ, Ziels RM, Strand SE, Gough HL, Stensel HD. Biodegradation kinetics of $17 \alpha$-ethinylestradiol in activated sludge treatment processes. Environ. Eng. Sci. 2015;32:637-646.

4. Johnson AC, Williams RJ. A model to estimate influent and effluent concentrations of estradiol, estrone, and ethinylestradiol at sewage treatment works. Environ. Sci. Technol. 2004;38:3649-3658.

5. Tran NH, Urase T, Ngo HH, Hu J, Ong SL. Insight into metabolic and cometabolic activities of autotrophic and heterotrophic microorganisms in the biodegradation of emerging trace organic contaminants. Bioresour. Technol. 2013;146:721-731.

6. Khunjar WO, Mackintosh SA, Skotnicka-Pitak J, Baik S, Aga DS, Love NG. Elucidating the relative roles of ammonia oxidizing and heterotrophic bacteria during the biotransformation of 17 alpha-ethinylestradiol and trimethoprim. Environ. Sci. Technol. 2011;45:3605-3612.

7. Ozkok IP, Rehman A, Yagci N, Cokgor EU, Jonas D, Orhon D. Characteristics of mixed microbial culture at different sludge ages: Effect on variable kinetics for substrate utilization. Bioresour. Technol. 2012;126:274-282.

8. Grady CPL, Smets BF, Barbeau DS. Variability in kinetic parameter estimates: A review of possible causes and a proposed terminology. Water Res. 1996;30:742-748.

9. Munz G, Szoke N, Oleszkiewicz JA. Effect of ammonia oxidizing bacteria (AOB) kinetics on bioaugmentation. Bioresour. Technol. 2012;125:88-96.

10. Widdel F, Bak F. Gram-negative mesophilic sulfate-reducing bacteria. In: Balows A, Truper HG, Dworkin M, Harder W, Schleifer KH, eds. The prokaryotes: A handbook on the biology of bacteria: Ecophysiology, isolation, identification, applications. New York: Springer-Verlag; 1992. p. 3352-3378.

11. Rongsayamanont C, Limpiyakorn T, Law B, Khan E. Relationship between respirometric activity and community of entrapped nitrifying bacteria: Implication for partial nitrification. Enzyme Microbial Technol. 2010;46:229-236.

12. Shi J, Fujisawa S, Nakai S, Hosomi M. Biodegradation of natural and synthetic estrogens by nitrifying activated sludge and ammonia-oxidizing bacterium Nitrosomonas europaea. Water Res. 2004;38:2323-2330.

13. Gerards S, Duyts H, Laanbroek HJ. Ammonium-induced inhibition of ammonium-starved Nitrosomonas europaea cells in soil and sand slurries. FEMS. Microbiol. Ecol. 1998;26: 269-280.

14. APHA-AWWA-WEF. Standard methods for the examination of water and wastewater. 20th ed. Washington D.C.: American Public Health Association, American Water Works Association, Water Environment Federation; 1998. p. 4-91-4-143.

15. Rotthauwe JH, Witzel KP, Liesack W. The ammonia monooxygenase structural gene $a m o A$ as a functional marker: Molecular fine-scale analysis of natural ammonia-oxidizing populations. Appl. Environ. Microbiol. 1997;63:4704-4712.

16. Martens-Habbena W, Berube PM, Urakawa H, De la Torre JR, Stahl DA. Ammonia oxidation kinetics determine niche separation of nitrifying archaea and bacteria. Nature 2009;461: 976-979.

17. Koops HP, Purkhold U, Pommerening-Röser A, Timmermann G, Wagner M. The lithoautotrophic ammonia-oxidizing bacteria. In: Dworkin M, Falkow S, Rosenberg E, Schleifer $\mathrm{KH}$, Stackebrandt E, eds. The prokaryotes: An evolving electronic resource for the microbiological community. New York: Springer-Verlag; 2003. p. 778-811.

18. Wood PM. Nitrification as a bacterial energy source. In: Prosser JI, ed. Nitrification. Oxford: IRL Press; 1986. p. 39-62.

19. Suzuki I, Dular U, Kwok SC. Ammonia or ammonium ion as substrate for oxidation by Nitrosomonas europaea cells and 
extracts. J. Bacteriol. 1974;120:556-558.

20. Limpiyakorn T, Kurisu F, Sakamoto Y, Yagi O. Effects of ammonium and nitrite on communities and populations of ammonia-oxidizing bacteria in laboratory-scale continuous-flow reactors. FEMS. Microbiol. Ecol. 2007;60:501-512.

21. Forrez I, Carballa M, Noppe H, De Brabander H, Boon N, Verstraete $\mathrm{W}$. Influence of manganese and ammonium oxidation on the removal of $17 \alpha$-ethinylestradiol (EE2). Water Res. 2009;43:77-86.

22. Ren YX, Nakano K, Nomura M, Chiba N, Nishimura O. Effects of bacterial activity on estrogen removal in nitrifying activated sludge. Water Res. 2007;41:3089-3096.

23. Yi T, Harper WF. The link between nitrification and biotransformation of 17alpha-ethinylestradiol. Environ. Sci. Technol. 2007;41:4311-4316.

24. Yi T, Harper WF, Holbrook RD, Love NG. Role of particle size and ammonium oxidation in removal of 17alpha-ethinylestradiol in bioreactors. J. Environ. Eng. 2006;132:1527-1529.

25. Andersen H, Siegrist H, Halling-Sorensen B, Ternes TA. Fate of estrogens in a municipal sewage treatment plant. Environ. Sci. Technol. 2003;37:4021-4026.

26. De Gusseme B, Pycke B, Hennebel T, et al. Biological removal of $17 \alpha$-ethinylestradiol by a nitrifier enrichment culture in a membrane bioreactor. Water Res. 2009;43:2493-2503.

27. Forrez I, Carballa M, Boon N, Verstraete W. Biological removal of $17 \alpha$-ethinylestradiol (EE2) in an aerated nitrifying fixed bed reactor during ammonium starvation. J. Chem. Technol. Biotechnol. 2008;84:119-125.

28. Vader JS, Van Ginkel CG, Sperling FM. Degradation of ethinylestradiol by nitrifying activated sludge. Chemosphere 2000;41:1239-1243. 